\title{
Commentary on Ruben Berrios' book Growth without development. Peru in comparative perspective
}

\section{Carlos Mallorquín}

My comments on Ruben Berrios' book Growth without Development. Peru in Comparative Perspective ${ }^{1}$, has a twofold purpose, a brief description of contents followed by a series of points to certain aspects of the text which can be named as a critique, since readers should be advised on the existence of an alternative narrative, which can be called: «Latin American Structuralism».

Whether one believes that some «countries» «fall behind» comparatively to others with respect of «growth», «equality» or other indexes which can be conjured up, the text offers a wide variety of stats which show the evolution of Peru's economy in various economic or social sectors.

It gives a general and well informed description of certain tendencies of the economic evolution, brings into the image its relative standing with respect of its own heterogeneous social evolution and condition since the 1960's, but also in relation to other countries which are used as the dissimilar register, although perhaps too little said of its multilingual and cultural configuration.

The argument in the first chapter, includes a broad discussion of the western-centric literature ${ }^{2}$ around the theoretical and political distinction between «growth» and «development». The dichotomy «state

${ }^{1}$ Lexington Books, Maryland.

${ }^{2}$ Anglo-Saxon and/or European discourses 


\section{CARLos MALLORQuín}

versus market» hegemonizes most of the narrative in the text, not just in the chapter in question, but as will be emphasized further ahead of this article, the counterposed dichotomy is in fact impertinent when Latin American Structuralism vision is examined. Notwithstanding, the book underlines the importance of creating some sort of synergies between public and private agencies to generate growth and development: achieving a higher rate of growth or GDP (gross domestic product), which in turn does not guarantee a more equal distribution of income among the population in question, or a bigger slice of the pie.

The issue is related to constructing, reforming, or generating a series of social relations or institutions, which ensures that an increasingly rising proportion of the fruits of technical progress reaches the lower income echelons' of the population. Via rising incomes or lowering costs, and simultaneously transforming the social and technical division of labor economies «develop». The orthodox neoclassical perspective (neoliberalism), argues that the market will resolve the transformation automatically if the «market» is left to its own organization or unimpaired; while the so called «statist» vision implicates important reforms and guiding lines by governmental policies or the state in certain entrepreneurial activities.

The comparative perspective propounded by the book implies bringing into the picture an entity with which to mirror distinct countries' evolution: Chile's and Korea's economic evolution «growth» and / or «development» form the contrasting picture which Peru did not, or could not, assimilate, these consequences are represented in a series of statistically related information with education, reduction of poverty, or the HDI (Human Development Index) elaborated by United Nations, or World Bank measures and the OECD. 
Peru seem to «lack» certain types of «robust institutions» and stability unlike Chile ${ }^{3}$ and Korea. What I want to emphasize in these comparisons are the so called lessons which can presumably be «learned», but which only tends to assert that the more «market» the better, or the less state or regulations, the better for economies. It also tends to forget local regional history and power asymmetries among and between different economic formations (center and periphery power asymmetries). Without a doubt, Korea's description of its «outstanding» «economic» success underlined by the author is an event which needs explaining, but it has to be put in context (Fernández, 2017): a 6000 million dollar package during the 1960's by the USA and an Asian protective commercial and industrial belt to elaborate policies which in part were argued theoretically by Latin American Structuralism: educational, fiscal and land reform and not least an innovative protected lead industrial policy in its first years. Korea's authoritarian social and political trends can be seen as a good example of the Manu military pushed by the Chilean dictatorship after 1973 with the corresponding thriving economic rates of growth, but the same can be said of Stalin's «successful» industrialization drive!

But most importantly, when the Asian examples are brought to bear (the so called Asian «tiger» or little tigers»), to promote and explain certain forms of market reforms and the «successful» «industrialization» process (Guillen, 2018), we ignore the intensely antagonistic horizon within the Latin American region and its military regimes, in general safeguarded by USA policies, which in turn generated a whole set of democratic struggles during the 1970's and 1980's.

${ }^{3}$ As I write these words, I read of an untold number of people gravely injured and deaths in the Chilean alamedas. 


\section{CARLOS MALLORQUÍN}

The contrasted «extractive» ${ }^{4}$ versus «productive» economy evolution, as an image respectively followed by Peru and Korea, misses the point that what is at issue is the reconstruction of certain social and economic boundaries within and between certain units of production, or regions. Again, the Latin American Structuralist vocabulary which highlights the heterogenous aspects of the agents and «economic» regions, belies the idea of a univocally «centrifugal» market force of mercantile or commodified social relations.

Heterogeneity is the product of power asymmetries, between and within agents and regions, hence Prebisch's thesis on the innate character of «Centre-Periphery» antagonism, which does not relate necessarily to distinct economic formations, commercial product specific exchanges (primary vis a vis industrial products), since there are «center's», or «peripheries» within the periphery itself, which can only be understood as a consequence of the heterogeneity in question. For example, see Peru's differing rates of growth and commercial logics among diverse regions, which are generally rounded up into the category of a «mineral» exporter country (Orihuela y Echenique, 2019), or the so called «subsistence capitalism» (Lust, 2019), by the existence of a diverse organizational form of the small units of production, both of which, in a different language reproduce Latin America Structuralist theoretical position. However, both narratives, the former and the latter, within the western-centric perspectives evades not only its ethno-centric postures with respect of the understanding required as to the form and contents of agents, regions, institutions, but worst of all, its own geographically and cultural blind spot of the existence of alternative discourses.

${ }^{4}$ This counterposition is repeated in much of the Marxist literature, and not new, Latin American Structuralists during the 1950's and 1960'used the term «enclave» to explain its negative effects, and hence their «structural reforms» plans and State participation. 
Latin American Structuralism, (and especially Prebisch) insists since the 1940's in the importance of the market, and actually projected the creation of a series of interlocking zones and agents which could be turned and named as «markets», hence its emphasis in land reform, by the way, it was these so called «capitalist» aspects of the policies which gave its fuel to the Dependency school critique to structuralism. Fiscal and state reforms and hence the agency of the State was crucial in its vision; neoliberalism deconstruction of structuralism into a «statist» centered economic policy perspective certainly was successful. But central to its vision was the theme of constructing a more equal world, through transforming the power asymmetries, which in turn explained the heterogenous characteristics of the economic formations (Mallorquín, 2017; 2019).

An approach which recovers the importance of considering the productive and distributive aspects of the social categories, implies linking theoretically the latter in terms of the asymmetries' of power of which they are its effects: agents and their conditions of existence are the consequence of the antagonisms and power asymmetries, and these agents need not necessarily be «human individuals» (all sorts of corporations, «universities», «trade unions», «households», «states», etcetera), all of which have the pertinent recognition mechanisms through which to undertake choice-decisions. On the other hand, their antagonistic mode of constitution (the social relations), are always a contingent, transient characteristic, which forms part of the explanation to understand the heterogenous features of most agents. The power asymmetry generates the heterogenous characteristic of the agents: it relates to the mode by which agents possess in separation certain of their conditions of existence or of the units of production, the «remainder» of which have to be, negotiated, bought, etcetera, especially 


\section{CARLOS MALLORQUÍN}

with other «economic» agents strictly speaking. Therefore the antagonistic moment, always contingent, is constitutively associated with the «price» or «value» which they can enforce or assume, whether «capital» or «labor»: Latin American structuralism claims that these categories have no general form of being or unity: on the one hand, these entities are not necessarily «human», but on the other, most important also they possess in separation, with respect other agents, no more than specific aspects of their conditions of existence.

\section{References}

Guillen Romo H. (2018). Caminos del desarrollo del tercer mundo al mundo emergente. México: Siglo XXI.

Lust, J. (2019). «The rise of a capitalist subsistence economy in Peru». Third World Quarterly, 40(4), pp. 780-795.

Mallorquin, C. (2017). «A southern perspective on development studies: contributions from Latin America». Cinta de Moebio (58).

Mallorquin, C. (2019). «How economics forgot power». Estudios Regionales en Economía, Población y Desarrollo (53).

Orihuela, J.C. y Echenique, G.V. (2019). «Volatile and spatially varied: the geographically differentiated economic outcomes of resource-based development in Peru, 2001-2015». The Extractive Industries and Society.

Ramiro Fernandez, V. (2017). La trilogía del erizo-zorro. Redes globales, trayectorias nacionales y dinámicas regionales desde la periferia. Barcelona: Anthropos/Universidad Nacional del Litoral. 